\title{
Women's Writing and Women's Culture: Meanings of Domesticity in Prose by Latvian Women Writers
}

\author{
ZITA KĀRKLA
}

\begin{abstract}
Housework that women do has no lasting effects, produces nothing tangible, gives no sense of closure and, for this reason, it is perceived as trivial, mindlessly repetitive, and invisible. However, examining texts by two Latvian women writers Regina Ezera and Inga Ābele, it can be argued that not only the social context of a woman's situation is inscribed through her domesticity, but something important about female consciousness is also revealed. Employing various household items - a kettle boiling over, broken glass, an old washing machine, linen towels, etc. - writers mirror the internal emotions of their women characters through vignettes from everyday life. Seemingly insignificant female-driven domesticity serves as a setting where it is possible for women to unfold heavy memories and tell their stories, giving shape to relationships between women. And domesticity's ability to bring not just physical order, but also link matter to spirit and tie connections with nature and the self is emphasized.
\end{abstract}

Keywords: feminist criticism, Latvian literature, women writers, housework

The female experience of housework has, for the most part, been treated as trivial, personal, unworthy of analysis, and is often overlooked. Considering the study of housework, Judith Levin writes: housework seldom produces a concrete product; housework is endless; it is often done in isolation from other adults; housework is unpaid, and for all the above reasons, housework is often considered to be no work at all. (Levin 1993: 287) However, by dismissing the subject as insignificant, petty, and not worthy of our attention, we miss the opportunity to reveal something important, not only about woman in the world, but also about the inner worlds of women, or as Bettina Aptheker writes: "One way to understand women's consciousness is to make visible the cultures it creates," defining culture as "the ordered system of meanings in terms of which people define their world, express their feelings and make their judgments." (Aptheker 1989: 13) Women writers have used images and metaphors of domesticity like cooking, cleaning, gardening, knitting, etc., to express emotions, describe relationships, and convey values. The aim of this paper is to examine the portrayal of domesticity in texts 
by Latvian women writers Regīna Ezera and Inga Ābele, asking such questions as: How do descriptions of everyday activities contribute to the author's general goal? What role does domesticity play in the characters' lives? How does it drive the plot? What subtexts, values and attitudes does it reveal? How are women's thoughts, emotions, and consciousness inscribed in portrayals of domesticity?

\section{Women and Domesticity}

In the story Saules atspulgs (Reflection of the Sun, 1969) author Regina Ezera uses two parallel narratives - one tells about a husband, Žanis Vanags, the other, about his wife, Elza. The choice to use two concurrent narratives to tell the story marks a sharp contrast not only between inner worlds of two persons in general, but between women's and men's worlds, emotions, and desires particularly. While Žanis Vanags works in the city as a magazine editor, his wife Elza is a housewife. She resides in countryside where her husband visits her on weekends. Relative accomplishment in the public sphere, linked to the intellectual work that Vanags does, is contrasted with the physical, unseen daily tasks that Elza performs. Elza's household tasks include preparing meals, setting the table, serving meals, clearing the table, and doing dishes. Those are the tasks that are ruled by routine, never give any tangible results, never end, and make Elza confess: "It seems that all I have done the whole of Saturday and Sunday is laying and clearing the table." (Ezera 1980: 151 $)^{1}$ When one Sunday Elza's husband, Žanis, together with her brother, walk to the woods to pick mushrooms, Elza stays at home despite the fact that she would also like to go, because she has to clear breakfast table, do the dishes, walk to neighbors for milk, and make dinner. Elza ends up doing the kind of housework that cannot be deferred - meals require daily attention - and the essential characteristics of her work is isolated. Elza stays in the country house alone, and even on weekends when her family comes to visit, nobody helps her with household tasks; they are invisible - noticed only if not done. For example, Elza's absence at the breakfast table is noticed only when others run out of cheese and fresh coffee, thus Elza, by doing invisible tasks, has become invisible herself.

Another housewife, Vizma, is described in Ezera's story Vasara bija tikai vienu dienu (Summer Lasted for Just One Day, 1974). While Vizma's husband, Valters, works as a forester spending his days in woods, Vizma takes care of their household - a small child, animals, the garden, and meals. One Sunday, when her husband goes hunting, Vizma stays at home, busy with her daily chores, and contemplates:

1 All translations by Zita Kārkla unless stated otherwise. 
Sunday, Sunday...Why were such Sundays invented? Melancholy is suffocating. So it seams that life passes without me...leaves like a train, which I see in my dreams every night. A housewife... with a child and pots. Even a year ago... even half a year ago it seemed to me that a housewife is a philistine, even a loafer, but now sometimes in the evenings my legs and arms hurt from the hard work...and my heart. (Ezera 1974: 107-108)

Unseen daily tasks never end, even on Sundays the routine of domesticity continues. To the young woman it seems that there is no way out; she is caught in her daily routines, imprisoned in housework, while her life passes. A similar family situation recurs in the second chapter of another of Ezera's texts - Zemdegas (Smouldering Fire, 1977) - "Zaķis ar divām sirdīm, jeb stāsts par Vili Pērkonu un ari par Ritmu" ("A hare with two hearts, or the story about Vilis Pērkons and also about Ritma"). Here again the author chooses to tell two parallel stories: one concerning a husband, Vilis Pērkons, who goes on a hunting trip together with some other men on Sunday. The other story is about his wife, Ritma, who meanwhile stays at home doing laundry:

It was Sunday and Ritma could still stay in bed if she wanted [...], however when she spotted stars through the window in the morning darkness, she guessed that the weather would be clear and the linens should be washed, she should pull herself together, get on with it, and vanquish the pile of sheets, pillowcases, towels, and shirts once and for all, because washing that has been fluttering in the wind and freezing in the cold has a different whiteness and a different smell to it. (Ezera 1977: 104)

As Ezera ironically writes: Ritma is "busy with work and more work and free as a bird" on her Sunday off. Vilis is free to go hunting on his day off, he is free to pursue a hobby, while Ritma's 'freedom' means piles of laundry that need doing. Ritma, a wife and the mother of two sons, and the only woman in the house. She is tied to household tasks, while the other members of her family expect "to be waited on, hand and foot, the male domain, the strong sex. A holiday for everyone - only not for her, no never for her." (Ezera 1977: 132) ${ }^{2}$

Almost 30 years later another Latvian writer Inga Ābele inscribes the same opposition between men's and women's worlds in her short story Marja ir prom (Marja is gone, 2004). The woman is the one tied to the circular activity of domesticity. The main character's husband is a forester who spends his days in the woods, while his wife stays at home taking care of the children, the animals, and

2 Translation by Inta Ezergaile. 
the household, immersed in the never ending tasks of daily life. Domesticity in this story is contrasted with the freedom that, according to the wife, her husband has when he works in the woods. The woman confesses, half laughing, half crying in despair: "I live in the middle of the forest but I can never get to the forest, never get to be in the forest completely like that man, my husband, who spends all day there - oh, lucky him!” (Ābele 2004: 191) The housewife in Ābele's story feels suffocated by the demands of household tasks. She feels that there are too many tasks to perform, too many interruptions, and not enough time to accomplish her work.

In these texts, home appears as a private, female-dominated space, distinct from the male world of work, reinforcing the doctrine of separate spheres. Writing about English literature, Sandra Gilbert and Susan Gubar make the contention that the overlapping spaces of home and private life, which are central to contemporary conceptions of the individual, delineate the woman as man's foil, prone to circular activity. (Gilber, Gubar 1977: 17) Domesticity's association with corporeality also means that women's activity is perceived as more physical than mental and the key result of this association is that the gendered equation of man/ woman as "separate yet equal", becomes the subordination of the female by male. Regina Ezera, an author who, as Inta Ezergaile points out, is "strongly aware of gender whose consciousness has been sharpened by the hypocritical stance toward women's status that we obtained under the Soviets" (Ezergaile 1998: 202) turns to housekeeping, in addition to other things, in an attempt to reveal an objective representation of social reality, reflecting that, "Soviet quotidian existence was dominated by gender inequality, which revealed the USSR's much-vaunted gender egalitarianism to be illusory." (Sutcliffe 2009: 5) Ezera's choice to show women busy with housework on Sundays is not coincidental either, as it emphasizes the sharp contrast between men's and women's lives in Soviet Latvia, where women were the ones to carry the brunt of the domestic burden. However, Ezera does not use women's daily work only as a venue for commenting on often overlooked 'women's issues', because she does so from a markedly artistic viewpoint that unfolds the mental, emotional, and spiritual lives of women through their domestic activities. Ābele, on the other hand, uses the everyday not so much as an arena for discussing woman's social problems, but as a way of reaching inside a woman's consciousness, through domesticity and her attitude towards it, revealing the inner life of the main character.

\section{Telling One's Story through Domesticity}

Employing different household props - a kettle boiling over... sizzling and hissing, broken glass, dishes, an old washing machine, red fabric, etc. Ezera mirrors the 
internal emotions of her character through the ongoings of everyday. In Zemdegas, Ezera slips in several episodes that reveal Ritma's longing for her femininity as the very essence of herself. For example, there is an episode when Ritma notices her reflection in a dark window and feels a sudden and pleasing self-awareness but, instead of remaining with her sense of self, she turns away from the image and gets ready to do the laundry; she pushes the washer out from under the stairs, makes a fire in the stove, sorts the dirty laundry, and brings water from the well. Ritma calmly "harnesses herself in the cartful of work that needs to be done" (Ezera 1977: 107). The customary performance of household tasks relieves her of fluctuating between joy of life and melancholy. The tasks distract her from thinking and longing. However, simultaneously, the fatigue that comes from suppressed anger and loss of contact with her own being are expressed through domestic images - the clouds of vapor that fall over the pot boiling with laundry express the resentment that Ritma feels.

Ritma's deepest anger comes from her need for genuine relationships that is not fulfilled within her family:

As though it ever occurred so briefly to any of them what she was thinking and feeling, what she desired and longed for. As though she were just a machine, like this old Riga-brand washer - a motor with no soul. (Ezera 1977: 119) ${ }^{3}$

Ezera compares Ritma to a washing machine, she uses a domestic image to illustrate the role Ritma plays at home - she is a useful household appliance that can be shoved under the stairs once the job is done. Ezera also uses the domestic setting to signal trouble in the relationship between Ritma and her husband. When Ritma invites a neighbor, who unexpectedly appears at the door, into her living room, she suddenly notices that the room is cold and messy, the stove has not been lit, and different things, mostly belonging to Vilis, are scattered around the room, because while, "taking care of breakfast and laundry, [she] has not yet managed to straighten up anything” (Ezera 1980: 134). This domestic episode illustrates not only physical chaos - Ritma is expected to clean up after others in her family on her day off - but also the chaos in the relationship.

In Ezera's story Saules atspulgs, cooking and cleaning to endure childless marriage, Elza sublimates her emotions into domesticity. Elza's true feelings are not spoken out loud; instead they are mirrored through household items. For example, after finding out that her husband will be promoted, Elza thinks to herself ironically: "you are climbing to the top, Elza!" (Ezera 1980: 121), and right at that very

3 Translation by Inta Ezergaile. 
moment steam escapes with a hissing sound from the kettle where Elza is boiling water for washing the dishes, reflecting Elza's dissatisfaction with her situation. In another episode Vanags calls himself and Elza "two fatties", adding that they would need more physical exercise. And at the same time: "Something boils over on the stove, fizzling and bubbling." (Ezera 1980: 136) Elza boils water for washing dishes or when preparing meals. It is an ordinary, unremarkable task until Elza's emotions "boil over" on the inside during her conversations with Žanis, and Ezera draws attention to the sounds of the kettle boiling over.

There is another household trifle - a blue glass with a broken off leg that is used to give Elza's emotions physical form, alerting the reader to tensions beneath the surface. While doing the dishes after her birthday party, Elza discovers blue glass that has been broken in two. A seemingly insignificant domestic occurrence - a blue glass with a broken stem -reflects the chaos of Elza's marriage. What she once thought to be whole is now broken into two separate pieces. However, Elza's response to the collapse of her marriage is the same as when she finds the broken glass:

Orderly, polite guests. Nothing has been burned, spilled, or smashed. And the one glass that perished on the altar of hospitality, was broken by Elza herself. [...] Nothing tremendous has happened, it's her own fault. (Ezera 1980: 244)

Ābele's story, Marja ir prom, begins with a gloomy autumn landscape that mirrors the main character's inner state, the sense of failure that she feels about her life:

She was pulling up the pea stalks and looking at her hands, blue from the cold. 'Only wet snow is missing here for complete happiness,' she thought, tiredly plucking pea pods from their stalks, which, grieving about the inevitable approach of winter, had quietly withered, drawn into themselves, and blackened. (Ābele 2004: 83)

Pea stalks in the garden that the woman tends, embody her emotional position: it is she who quietly lingers, drawn into herself, feeling musty and blackened. She blames her suppressed feelings on the kind of life she leads, immersed in domesticity. Later, her emotions are compared to another household item - linen towels: "For one third of her life children, cows, and pea stalks were enough for her, because her feelings had become rare and easy to deal with, washable and foldable like linen towels in the closet." (Ābele 2004: 191) Since women had been responsible for the weaving of cloth and the making of clothes for centuries, woven linen towels also evoke a sense of women's culture. The domestic realm 
is also what gives shape to the relationship between the main character and her female tenant. The conversation between the two women that brings them closer together concerns domesticity and takes place in the middle of it. During the conversation that becomes a turning point in their relationship the main character is in the midst of doing her everyday chores - picking blueberries, milking the cows, going to the bus station to pick up children. Although she doesn't have time to spare for talking to a stranger, she reveals important things about herself in a short conversation. After an eruption of emotion, relieved that she had the chance to shout out her frustrations with her life to the other woman, she feels calmer and becomes friendly with the summer tenant. The episode suddenly makes her realize that she has not had any women friends since she graduated from university and moved to the house in the middle of the forest.

In Ezera's story Saules atspulgs a relationship between two women - Elza and Guna, an older woman who had been Elza's father's mistress - takes place in the midst of daily tasks. When Elza visits Guña, Guña is busy with her chores - milking the goat, kindling the fire in the stove, boiling potatoes for the pigs, cleaning the mushrooms that Elza has brought. Elza learns Guña's story in the very particular intimate context of female-driven domesticity. While confiding her traumatic past to Elza - an unhappy marriage, the death of her children, and life after WWII Guña keeps busy her with housework. The insignificant domestic ongoings serve as a setting where it is possible for Guña to unfold heavy memories. When Guña remembers her dead children the kettle boils over and a moment later, when Guna mentions that Elza needs a child so that she doesn't walk around moonstruck, Elza does not reply. Only the unpleasant sound of a knife scratching against a clay bowl can be heard. Ezera reveals Gun,'s story in the context of daily domestic work, connecting it with Elza's story through the theme of children and the use of the props of domesticity to mirror the internal emotions of her characters.

\section{Ambivalence of Domesticity}

"Symbolically, domesticity can represent womanhood, creativity, nature, mythic realities, and cyclical time, but also irrational forces, social oppression, emptiness, endless drudgery and earthbound heaviness," writes Jeannette Batz Cooperman (Cooperman 1995: 208). Ambivalence toward domesticity in Ezera's texts is marked by the women's attitudes towards their tasks. In Zemdegas the demands of the chores that can never be accomplished, never be abandoned, and are never appreciated by others imprison Ritma: "all morning and evening she had been striving to get out and away like from a prison" (Ezera 1977: 159). However, the way in which domestic labor can bring order from chaos - not just physically, but 
KĀRKLA

mentally and emotionally - is also inscribed in a scene where Ritma hangs freshly washed laundry:

\begin{abstract}
She walked by and between the sheets, holding a bowl with pegs, slowly forgetting both Aigars and Vilis, calming down and even becoming joyful, because it was so beautiful when clean sheets fluttered across her like white wings, smelling fresh - not quite like after snowfall, nor quite like after sweet-flag, and it again came to her mind - how little, how surprisingly little, is necessary for human happiness. (Ezera 1977: 139)
\end{abstract}

Through doing laundry, the most hated of all household tasks for many generations, Ezera reveals the ambivalence Ritma feels toward the domesticity in her life. Ezera doesn't deny Ritma neither the pain nor the artistry of her tasks, as Ritma simultaneously loathes the physical difficulty and time-consuming nature of her work, but finds it possible to enjoy certain aspects of the process. Hanging the wash out to dry, she finds it aesthetically pleasing and enjoys the clean smell of the clothes. For Ritma this task not only helps her to bring physical order to her world, but it also links matter to spirit and helps her make connections between nature and the self.

In Saules atspulgs, even during emotional crises, Elza's domestic chores continue unimpeded. She continues to cook, serves the meals, clears the table, and does the dishes. Her domestic activity is both an act of subservience and her response to emotional crisis, a way to find strength by following her prescribed routine. After her birthday guests have left, Elza clears the dishes from the farewell meal, washes the floors, throws open the windows to let in the fresh air. By reordering the house, she reclaims the house for herself again, ordering not only the physical environment, but also her emotional state. In this episode the housework shows how order is made from chaos, both physically and psychologically. The rhythms of her work help Elza to feel whole and to heal psychologically as she restores the order that her unwanted guests had confounded.

In contrast to household tasks that have no lasting effects, produce nothing tangible, and give no sense of closure, the narrative of domesticity reveals that Elza was once an aspiring artist. She chose domesticity over art because she wanted to have a "real home". However, Ezera makes a connection between domesticity and art in the episode where Elza admires a sturdy, black clay jug with six tumblers made by an unknown artist. The clay jug that Elza admires is a practical object, good for holding milk, juice, tea, coffee. It is used for serving drinks, but at the same time it is one-of-a-kind, a genuine handcraft, contrasted against the fragile mass produced porcelain tea sets around it. Elza wants to think that a woman's hands created the clay jug with six tumblers. This assumption, together with Elza's 
admiration for the object, draws attention to the possibility of finding a means of self-expression through practical, functional objects crafted for everyday use. Thus, domesticity becomes a source of art, instead of a dam against it. Women's art can come from the domestic realm, and a woman's traditional domestic role can cut deep enough into her psyche to create art, and to express the difference between a thing imbued with understanding and emotion and a thing mechanically produced:

The big jug looks like a tree trunk with marks of cut off branches. [...] like a tree trunk that has turned into coal. Black against the porcelain sets painted with flowers, dashes and dots. A black woman against the white ones. (Ezera 1980: 206)

Ezera depicts the deep divide that exists between women's expected social roles and their inner or essential selves, revealing longings women feel that are not tied to domesticity. Although Elza has buried her art deep beneath the tasks of everyday life, she is an artist at heart, Ritma in Zemdegas is longing for her feminine being, and in Vizma's story swans ${ }^{4}$ flying over the woods symbolize her desire for things beyond her physical reality. Ezera is genuinely interested in women's traditional work, including the harmonious ordering of daily life. By showing that daily rhythms can be psychologically healing, the author shows the ability of her female characters to find the good in nature and physical objects - freshly washed laundry, clay jug, cooking, etc. Ezera confesses that she is attracted by the poetic in the everyday, saying that: "the most valued human ability is to spot beauty in small things, in trifles”. (Ezera 1984: 36) Elza's 'moment of revelation' when she admires the clay jug, Ritma's moment of physical and spiritual harmony while hanging laundry to dry, and Vizma watching the swans over the forest, are all descriptions of women who are captivated by the poetic in the ordinary.

A point of transformation for the main character in Ābele's story Marja ir prom is when she realises that she is pregnant - suddenly she notices a certain order in the way she lives her life and performs her tasks, even the cyclical nature of household chores gains a new significance for her. The meaning of domesticity in her life becomes ambivalent - it imprisons while providing security. If in the beginning of the story there is a sharp contrast between a man's freedom and a woman's domesticity, at the end of the story the same opposition: man/woman; man's work/woman's work is seen as complementary and harmonious, bringing

4 The swan is an ambivalent symbol - it can mean light, transformation, and death all at the same time. In Ezera's story it also expresses Vizma's feminine essence and her longing for spirituality. 
order to a chaotic world. The tasks themselves have not changed, but the main character's attitude towards her domestic tasks has changed, sustaining domestic rhythm in connection to seasonal rhythm. In The Heroine in Western Literature Meredith A. Powers writes about women who are able to descend into realm of undifferentiated and irrational, the realm that "admits rage and grief, attends to the seasonal rhythms of life and death" (Powers 1991: 188). This alternative view of consciousness is what Ābele's character experiences recognizing that her life is dominated by the seasonal rhythms of life and death and the cyclical nature of time. It is characteristic for several of Ābele's texts to reveal a woman's dilemma between freedom and home. In the story Marja ir prom, the female character chooses home, recognizing domesticity as a realm where she can gain both strength and self-knowledge and a new wholeness. Rather than journeying into the world to escape domesticity, she makes a journey within herself in the middle of her everyday tasks.

It is significant that woman in the story questions the ability of language to express and contain what she really feels. Her relationship with Marja's mother in a foreign language helps because it "ties tongues in knots leaving more room for sights" (Ābele 2004: 192). She is connected with her summer tenants in an emotional way that can't be explained in rational terms. And when she wants to tell her husband about Marja's death again she realizes that language is insufficient to communicate her complex feelings, it will take too long to explain everything in words and most likely it won't have any meaning for him. Language has been constructed within a culture that has traditionally privileged a model of rational thought over emotion. Sidonie Smith, thinking about woman's subjectivity, writes that when inhabiting a domesticating space, "a space located closer to nature and necessity, a space of immanence and immediacy," a woman exhibits the less authoritative "feminine" mode of engagement with the world, also characterized as intuitive, irrational, and practical. (Smith 1993: 14) It can be argued that the woman in Ābele's story engages with the world in more intuitive, irrational way, as she is more open to rituals and symbols that build an imaginative bridge between the visible and the invisible, shattering the boundaries of space and time. The main character's choice to name her unborn child Mare, a name that resembles Marja, the dead woman's name, implies her recognition of the biologically-based temporal cycles - the seasons, sex and reproduction, life and death, where being and non-being exist together and become ordinary.

In Women's Time, Julia Kristeva links both cyclical time and monumental, allencompassing, infinite time with female subjectivity, as it emphasizes repetition and eternity. Kristeva writes: "On the one hand, this measure preserves cycles, gestation, the eternal return of biological rhythm that is similar to the rhythm of nature." (Kristeva 2002: 354) According to Kristeva, these cycles unite us with 
"extrasubjective", cosmic time and deep, unnamable joy. And on the other hand there is the enormous presence of a non-linear, monumental temporality, without cleavage or escape. (Kristeva 2002: 354) Both kinds of time are present in Ābele's story - when the main character realizes that she is pregnant, she feels a transcendent connection between dead Marja and the new life growing inside of her, experiencing deep unnamable joy that is transformative. However, she is still caught in a monumental temporality without escape. In the last scene of the story, the woman is shown in the same landscape as in the beginning of the story, still immersed in domesticity in the middle of the forest.

The opposition home/woods is an important one both in Ezera's texts and in Ābele's story. In Ezera's text Zemdegas Ritma's husband goes to the woods to hunt; in the story Vasara bija tikai vienu dienu Vizma's husband is a forester. In Ābele's story the main character's husband is also a forester. In those texts the forest is a place that equals the world where the husband is free to move around, while his wife is tied to housework. At the same time the forest stands for feminine realm, the locus of timeless and the mythical. For example, both the wife in Ābele's story and Vizma in Ezera's story reside in houses that are situated in the middle of a forest, and for both of them the forest is simultaneously enticing, because it stands for the freedom that man has and woman desires, and dangerous as it physically imprisons these women in their homes, secluding them from the rest of the world. The woman in Ābele's story moves to a house in the forest after marrying a forester. She "did not know the reason why her life, seemingly so full of potentiality (she has a degree in chemistry) was spent in the forest" (Ābele 2004: 190). Vizma in Ezera's story also marries a forester and moves to a house in the middle of the forest, and it seems to her that the forest will physically engulf her: "With darkness approaching, the trees transform, become silent, trunks and crowns fuse together turning into seamless walls, high ramparts that seem to be approaching." (Ezera 1964: 109) The forest, symbolically associated with the world of inner wisdom that comes from contemplation, can also indicate an occasion for important discoveries about the self, and both female characters reveal something essential about themselves in the middle of the forest and in the middle of domesticity. Vizma, a nineteen-year-old, who had pitied housewives, has now become one herself, and her story is a story about the development of personality, the psychological growth from youth to adulthood that occurs in the setting of domesticity. The woman in Ābele's story has reached middle age and she evaluates her life, looking for meaning. Her life seems dull to her, ruled by endless routine, she is sad and annoyed by the fact that she lives without anyone ever asking if she is happy or not. And only when she is able to make a connection between the cyclical nature of her everyday tasks and cyclical nature of life and death, she discovers the transcendental meaning of her life. Thus it can be argued 
KĀRKLA

that a woman living in the middle of the forest, immersed in everyday tasks, who gains important knowledge about herself, has a kind of timelessness about her. Despite the fact that the authors come from different generations: Regina Ezera wrote her story Vasara bija tikai vienu dienu during 1970s, while Inga Ābele wrote the story Marja ir prom in the beginning of the $21^{\text {st }}$ century, the female characters in both stories are somehow bonded across time by a mythical aspect of the feminine that becomes even more apparent because of the temporal distance that separates the two.

Elaine Showalter, one of the biggest supporters of a female-oriented criticism, which she calls gynocriticism, points out that women's writing "cannot be defined by biological essences, stereotypes of femininity, or nationalist myths. It must avoid both over feminization, the insistence that everything in women's writing can be explained by gender; and under-feminization, or the neglect of gender inscriptions in women's texts." (Showalter 1991: 17-18)

The same patterns of meaning recur in all of the texts examined here: the authors inscribe domesticity not only to reveal a character's social context - the role of a woman and her place in society - but to show their conscious awareness, their desires and talents, and to record their relationships. By showing how the emotional context can alter and distort the meaning of daily tasks, these authors reveal how a character's attitude toward the rest of her life shapes her attitude towards domesticity, thus through domesticity women's longings for genuine relationships are also revealed. Domesticity in the examined texts is described as ambivalent - it can imprison woman and restrict her self-expression, or it can be a creative space where a woman finds herself, emphasizing domesticity's power to bring order from chaos - not just physically, but mentally, emotionally and spiritually.

\author{
Zita Kārkla \\ zitakarkla@msn.com \\ Dzelzcel̦a 69 \\ LV-2008 Jūrmala \\ LATVIJA
}

\title{
Bibliography
}

Ābele, I. 2004. Marja ir prom. - Sniega laika piezìmes. Rīga: Atēna, 181-201.

Aptheker, B. 1989. Tapestries of Life: Women's Work, Women's Consciousness, and the Meaning of Daily Exsistence. Amherst, MA: University of Massachusetts Press.

Cooperman, J. B. 1995. The Broom Closet: Secret Meanings of Domesticity in Postfeminist Novels by Louise Erdrich, Mary Gordon, Toni Morrison, Marge Piercy, Jane Smiley, and Amy Tan. New York, Washington DC/Baltimore, Boston, etc.: Peter Lang, 1995.

Ezera, R. 1974. Vasara bija tikai vienu dienu. Riga: Liesma. 
Women's Writing and Women's Culture

Ezera, R. 1977. Zemdegas. Riga: Liesma.

Ezera, R. 1980. Saules atspulgs. - Saulespuķes no pērnās vasaras. Rīga: Liesma, 109-248.

Ezergaile, I. 1998. Nostalgia and Beyond: Eleven Latvian Women Writers. Lanham, New York, Oxford: University Press of America.

Kristeva, J. 2002. Women's Time [1977]. - K. Oliver, ed., The Portable Kristeva Reader. New York: Columbia University Press, 351-371.

Levin, J. 1993. Why Folklorists Should Study Housework? - S. T. Hollis, L. Pershing, M. J. Young, eds., Feminist Theory and the Study of Folklore. Urbana, IL: University of Illinois, 285-296

Powers, M. A. 1991. The Heroine in Western Literature. Jefferson, NC: McFarland\&Co., Inc. Showalter, E. 1991. Sister's Choice. Oxford: Clarendon Press.

Smith, S. 1993. Subjectivity, Identity, and the Body. Bloomington and Indianapolis: Indiana University Press.

Sutcliffe, B. M. 2009. The Prose of Life. Russian Women Writers from Khrushchev to Putin. Madison: The University of Wisconsin Press. 